Creative commons User License: CC BY-NC-ND

Abstracted by: EBSCOhost, Electronic Journals Service (EJS),

Google Scholar, Directory of Open Access Journals (DOAJ),

Journal Seek, Scientific Commons,

Food and Agricultural Organization (FAO), CABI and Scopus
Journal of Agricultural Extension

Vol. 21 (1) February, 2017

ISSN(e): 24086851; ISSN(Print); 1119944X

http://journal.aesonnigeria.org

http://www.ajol.info/index.php/jae

Email: editorinchief@aesonnigeria.org

\title{
Welfare Status of Rural Women Agro-processors' Participants in the Development Partnership in Higher Education Project in Osun and Oyo States, Nigeria \\ http://dx.doi.org/10.4314/iae.v21i1.4
}

\section{Mojisola Fauziyah Oyewole}

Department of Agricultural Extension and Rural Development

University of Ibadan, Nigeria

oyemojidola2@yahoo.com, 08023250459

\section{Abstract}

This study investigated the effect of participation in Development Partnership in Higher Education (DELPHE) project on welfare status of rural women processors in Osun and Oyo states. Data were collected using structured questionnaire on respondents' socio-economic characteristic, participation in the project activities, constraints faced in their processing activities and welfare status. Purposive sampling technique was used to select the two states for this study where the project was executed. Then stratified sampling technique was used to select respondents from participating communities to give a sample size of two hundred and sixteen (216) respondents from four and two local government areas from Osun and Oyo states respectively. Descriptive and inferential statistics were used to analyze data. Results showed that mean age of respondents was $43.9 \pm 12,63.4 \%$ had high level of participation, and lack of credit facilities (0.60) was indicated as the most severe constraint faced by respondents in their processing activities. The majority (83.3\%) of respondents had high welfare status. Welfare status was significantly influenced by participation ( $r=0.424)$. The study recommends that non-governmental organizations should replicate other intervention programmes among rural women processors in other rural communities to ensure sustainable agricultural development.

Keywords: Participation in DELPHE, Welfare of Women agro-processors.

\section{Introduction}

Over the years the rate of growth in agricultural production has stagnated and failed to keep pace with the rapid growing population. The potential of agro-processing sector as a major employer of labour is undermined, as a result of the presence of high incidence of poverty and low standard of living among Nigeria's population. As noted by Omotola (2008), Nigeria is richly endowed and the country should have no business with poverty. Yet rural poverty studies revealed the number of women living 
Creative commons User License: CC BY-NC-ND

Abstracted by: EBSCOhost, Electronic Journals Service (EJS),

Google Scholar, Directory of Open Access Journals (DOAJ),

Journal Seek, Scientific Commons,

Food and Agricultural Organization (FAO), CABI and Scopus
Journal of Agricultural Extension

Vol. 21 (1) February, 2017

ISSN(e): 24086851; ISSN(Print); 1119944X

http://journal.aesonnigeria.org

http://www.ajol.info/index.php/iae

Email: editorinchief@aesonnigeria.org

in absolute poverty in developing countries, including Nigeria increased from 400million in 1995 to 600 million in 2010 (International Fund for Agricultural Development, 2011).

Fabiyi et al (20) opined that women play a very significant role in agricultural processing activities, but are constrained by socio-cultural barriers to optimize their potentials. Many of developmental programmes such as Development Partnership in Higher Education are increasing their emphasis on assisting rural women to overcome the constraints they face to optimize their potentials. The DELPHE development project was funded by Department for International Development (DFID), United Kingdom between August, 2009 and September 2012. It was a collaborative intervention project between Obafemi Awolowo University, Ile-Ife, Nigeria, Institute of Agricultural Research and Training (IAR\&T), Moor plantation, Ibadan, Nigeria and the University of Newcastle Upon Tyne, United Kingdom (DELPHE, 2008).

The DELPHE project trained 400 rural women in Osun and Oyo states on selected enterprises which include: Cassava processing with value addition to improve nutritive quality and market acceptability, Oil palm processing and marketing, Moringa production and utilization, Soybean processing and value addition products, Bio-gas production and utilization, Organic fertilizer production and utilization, Sheep and goat rearing and marketing, and Capital generation and management. It was designed to exploit the inherent entrepreneurial capability of rural women. The project's thematic area was in business and enterprise development and had the main objective of enhancing improved rural standard of living through participation.

Oakely (2002), asserted that participation with regard to rural development include peoples involvement in decision making process in implementing programmes, sharing in the decision making process in implementing the programme, their sharing in the benefits of development programmes and their involvement in the effort to evaluate such programmes. Koyenikan and Ikhharea (2014), describe participation as a contribution to predetermined programmes and project, thereby enabling people to develop skills and abilities to make decisions and actions essential to their development. According to (Samuel, 2014) Participation implies 
Creative commons User License: CC BY-NC-ND

Abstracted by: EBSCOhost, Electronic Journals Service (EJS),

Google Scholar, Directory of Open Access Journals (DOAJ),

Journal Seek, Scientific Commons,

Food and Agricultural Organization (FAO), CABI and Scopus

\author{
Journal of Agricultural Extension \\ Vol. 21 (1) February, 2017 \\ ISSN(e): 24086851; ISSN(Print); 1119944X \\ http://journal.aesonnigeria.org \\ http://www.ajol.info/index.php/jae \\ Email: editorinchief@aesonnigeria.org
}

voluntary joint activities of people in economic and social activities which affects their lives. It is through participation that beneficiaries of any development programme have input into the priority setting, planning, implementation and evaluation of such development programmes designed to improve their standard of living.

The rural poor must participate in designing and operating a programme which involves them. Ogidefa (2010) stated the existence of wide gap in terms of standard of living and economic development between urban and rural women in Nigeria. The missing link has been due to past development programmes not appropriately addressing the welfare status component of the rural women. In view of the above, this paper addresses the following research objectives:

1. describe the socio-economic characteristics of respondents in the study area;

2. identify the constraints faced by the respondents in their agroprocessing activities in the study area;

3. ascertain the level of respondent's participation in DELPHE project activities in the study area and

4. determine the welfare status of respondents in the study area

\section{Hypotheses of the study}

$\mathrm{H}_{0} 1$ : There is no significant relationship between respondents' participation in DELPHE project activities and their welfare status.

\section{Methodology}

The study was carried out in Oyo and Osun states of Nigeria, which are the two states where the project was implemented Oyo State is located in the Southern geopolitical zone. Oyo state is between latitude $8000^{\prime} 00^{\prime \prime} \mathrm{N}$ and longitude $4^{\circ} 00^{\prime} 00^{\prime \prime} \mathrm{E}$. The state capital is Ibadan and it has thirty-three Local Government Areas (LGAs) distributed among three Senatorial districts. It is bounded in the North by Kwara State, in the South by Ogun State, to the East by Osun State and to the West by 
Creative commons User License: CC BY-NC-ND

Abstracted by: EBSCOhost, Electronic Journals Service (EJS),

Google Scholar, Directory of Open Access Journals (DOAJ),

Journal Seek, Scientific Commons,

Food and Agricultural Organization (FAO), CABI and Scopus
Journal of Agricultural Extension

Vol. 21 (1) February, 2017

ISSN(e): 24086851; ISSN(Print); 1119944X

http://journal.aesonnigeria.org

http://www.ajol.info/index.php/jae

Email: editorinchief@aesonnigeria.org

Republic of Benin. The total population of the state is 5591,589 (NPC, 2006) and land mass covers about 27249 sq $\mathrm{km}$.

The state lies in the southwest of the Niger valley in the savannah and rainforest zones of the country. It lies between latitude $700^{\circ}$ and $900^{\circ} \mathrm{N}$ and Longitude $2.75^{\circ}$ and $6.75^{\circ} \mathrm{E}$. It covers a total area of approximately $37,680 \mathrm{~km}^{2}$. The state is bounded in the north by Kwara State and Ekiti state and west by Six LGAs; four from Osun namely: Ife East, Egbedore, Ede South, Obokun, and two from Oyo state (Iddo and Akinyele) were selected purposively being the local government areas where the project was implemented.

Stratified sampling technique was used to select two groups from each of the communities in the local government areas based on the enterprise categories. The total Moringa women processors was 90 , Soybean women processors were 65,61 were Cassava women processors. The total sample size for the study was two hundred and sixteen (216). Structured interview schedule was used to collect data. Indices of participation (0-18) and welfare status (\$750 - 16,500) were generated. Data were analysed using descriptive and inferential statistics such as mean, percentages and Pearson Product Moment Correlation.

Dependent variable, welfare status of the respondents was measured by asking the respondents to state the actual amount they spend on households' basic items (such as food purchases, school fees, accommodation, utility bills, health etc.) within periods. The expenses were converted into monthly estimations. Thereafter, per capita expenditure was derived by dividing the respondents' household expenditure by the household sizes. The welfare categories were determined using National Bureau of Statistics (NBS, 2005) method. The highest Per Capita Expenditure (PCE) score was $\$ 16,500.00$ while the lowest score was $\$ 750.00$. The mean Per Capita Expenditures was derived as $\$ 5837.14$. The categorization of the PCE was done using the following criteria;

Between the least value and below $2 / 3$ of mean PCE $=$ Worse off

Between $2 / 3$ PCE and the maximum value of $\mathrm{PCE}=$ Better off 
Creative commons User License: CC BY-NC-ND

Abstracted by: EBSCOhost, Electronic Journals Service (EJS),

Google Scholar, Directory of Open Access Journals (DOAJ),

Journal Seek, Scientific Commons,

Food and Agricultural Organization (FAO), CABI and Scopus
Journal of Agricultural Extension

Vol. 21 (1) February, 2017

ISSN(e): 24086851; ISSN(Print); 1119944X

http://journal.aesonnigeria.org

http://www.ajol.info/index.php/jae

Email: editorinchief@aesonnigeria.org

\section{Results and Discussion}

\section{Socio-economic Characteristics of Respondent}

Table 1 shows the age distribution of respondents. It reveals that $58.3 \%$ of the respondents were within the age range of 41- 50 years with a mean age of $43.9 \pm 12$ years. These age groups are within the productive age. This implies that the majority of the respondents were in their economically active age, which means that their active participation in processing activities would bring about higher income for their improved welfare status. Mafimisebi (2007) asserted that most rural women in these economically productive age groups undertake various livelihood activities in their communities. Most (58.3\%) of the respondents were Christians, 39.4\% were Muslims while $2.3 \%$ of them were traditional worshipers respectively. This shows that Christianity is prevalent in the study area. Akinola (2010) in his study on community driven project in Nigeria, reported that most of the respondents in the study are actively involved in religious activities.

Table 1 shows that large proportion of respondents (57.2\%) had primary education. This implies that the educational level of respondents is relatively low. This could have influence on the ability of respondents to take advantage of training in order to acquire new skill and knowledge from the project for expansion of their processing enterprise which brings about more income and better welfare status. This is consistent with the findings of Hussain (2009), that respondents' attained higher educational status is expected to influence positive growth and development in their community.

Table 1 also reveal that $51.0 \%$ of the respondents had a household size of $5-8$ persons with a mean household size of $6.0 \pm 2.0$. Increase in number of people in a household is likely to exert pressure on the household expenditure and consumption which may have negative effect on their welfare status. Household size is one of the factors that determine the welfare status of the respondents (Olawuyi and Adetunji, 2013). 
Creative commons User License: CC BY-NC-ND

Abstracted by: EBSCOhost, Electronic Journals Service (EJS),

Google Scholar, Directory of Open Access Journals (DOAJ),

Journal Seek, Scientific Commons,

Food and Agricultural Organization (FAO), CABI and Scopus
Journal of Agricultural Extension

Vol. 21 (1) February, 2017

ISSN(e): 24086851; ISSN(Print); 1119944X

http://journal.aesonnigeria.org

http://www.ajol.info/index.php/jae

Email: editorinchief@aesonnigeria.org

\section{Table1: Distribution of respondents by socio-economic characteristics}

\begin{tabular}{llll}
\hline Variables & Percentages $(\mathrm{n}=216)$ & Mean & $\begin{array}{c}\text { Standard } \\
\text { deviation }\end{array}$ \\
\hline Age & 10.0 & \\
$21-30$ & 18.4 & 43.9 & 12 \\
$31-40$ & 58.3 & & \\
$41-50$ & 11.4 & & \\
51 years and above & 1.9 & & \\
Religion & 58.3 & \\
Christianity & 39.4 & \\
Islam & 2.3 & \\
Traditional & 27.4 & \\
Educational status & 3.4 & \\
No formal education & 10.0 & & \\
Adult education & 57.2 & & \\
Vocational & 1.0 & & \\
Primary & 1.0 & & \\
Secondary & & & \\
Tertiary & & & \\
& 31.0 & 6.0 & \\
Household size & 60.2 & & \\
$1-4$ & 5.5 & & \\
$5-8$ & 3.3 & & \\
$9-12$ & 2014 and above & & \\
\hline
\end{tabular}

Source: Field Survey 2014

\section{Constraints Faced by Respondents in their Processing Activities}

Table 2 presents the constraints faced by respondents on their various processing activities. It revealed that, lack of credit facilities $(0.60 \pm 0.48)$ was ranked $1^{\text {st }}$ as the most serious constraint faced by the respondents. Unstable price of processed products was ranked $2^{\text {nd }}$ by respondents $(0.56 \pm 0.51)$, while high cost of processing equipment $(0.46 \pm 0.44)$ was ranked $3^{\text {rd }}$, inadequate storage facilities $(0.33 \pm 0.29)$ was ranked $4^{\text {th }}$, lack of technological know-how $(0.30 \pm 0.63)$ was ranked $5^{\text {th }}$ while unavailability of land for processing activities $(0.18 \pm 0.25)$ was ranked $6^{\text {th }}$ by respondents. These constraints faced in the processing activities could be hindrance to improved productivity. This is confirmed by Fabiyi and Akande (2015) that rural women are faced with constraints in their processing activities, and this reduces their productivity 
Creative commons User License: CC BY-NC-ND

Abstracted by: EBSCOhost, Electronic Journals Service (EJS), Google Scholar, Directory of Open Access Journals (DOAJ),

Journal Seek, Scientific Commons,

Food and Agricultural Organization (FAO), CABI and Scopus
Journal of Agricultural Extension

Vol. XX (X) XXXXXXX, 20XX

ISSN(e): 24086851; ISSN(Print); $1119944 X$

http://journal.aesonnigeria.org

http://www.ajol.info/index.php/jae

Email: editorinchief@aesonnigeria.org

Table 2: Distribution of respondents on constraints faced by respondents on various processing activities

\begin{tabular}{lllll}
\hline S/N & Constraints & Mean & $\begin{array}{l}\text { Standard } \\
\text { Deviation }\end{array}$ & Rank \\
& & & & \\
\hline 1 & Lack of credit facilities & 0.60 & 0.48 & $1^{\text {st }}$ \\
2 & Unstable price of processed products & 0.56 & 0.51 & $2^{\text {nd }}$ \\
3 & High cost of processing equipment & 0.46 & 0.44 & $3^{\text {rd }}$ \\
4 & Inadequate storage facilities & 0.33 & 0.29 & $4^{\text {th }}$ \\
5 & Lack of technological know how & 0.30 & 0.63 & $5^{\text {th }}$ \\
6 & Unavailability of land for processing & 0.18 & 0.25 & $6^{\text {th }}$ \\
& activities & & & \\
\hline
\end{tabular}

Source: Field Survey, 2014

\section{Participation in DELPHE Project Activities}

Table $3 a$ reveals that majority of the respondents always participate in contribution to decision making $(0.86 \pm 0.75)$, meeting attendance $(0.85 \pm 0.70)$, participation in training $(0.84 \pm 0.69)$, regularity of payment of dues $(0.83 \pm 0.65)$, participation in group formation $(0.82 \pm 0.63)$ provision of required information at meeting $(0.81 \pm 0.0 .60)$, while respondents had low participation in obtaining revolving loan $(0.63 \pm 0.56)$, procurement of processing equipment $(0.59 \pm 0.48)$ and distribution and handing over of processing equipment $(0.55 \pm 0.43)$. The high percentage of respondents participation in training is because training ensures being exposed to some new processing practices that is expected to improve their processing skill, which will in turn improve their standard of living, participation in the meeting attendance may be because they are aware of the benefits from the project, thus they are eager and ready to participate in meeting attendance. Obtaining revolving loan is as a result of low business enterprise of women as reported by Dutt (2014) that women had low business enterprise, and their inability to secure bank loan to expand their business enterprise, they have to employ the available means of credit facilities such as revolving loan from their group to expand their business enterprises. Low participation in revolving loan might be because of limited amount of loan available, making it not enough for distribution among the members. 
Creative commons User License: CC BY-NC-ND

Abstracted by: EBSCOhost, Electronic Journals Service (EJS), Google Scholar, Directory of Open Access Journals (DOAJ),

Journal Seek, Scientific Commons,

Food and Agricultural Organization (FAO), CABI and Scopus
Journal of Agricultural Extension

Vol. XX (X) XXXXXXX, 20XX

ISSN(e): 24086851; ISSN(Print); $1119944 X$

http://journal.aesonnigeria.org

http://www.ajol.info/index.php/jae

Email: editorinchief@aesonnigeria.org

Participation in the procurement of processing equipment will assist the beneficiaries to procure processing equipment on their own. Due to the high cost of processing equipment, they are not affordable by the respondents individually, hence the need for cooperation by all group members to purchase the equipment and consequent rotation of the equipment among members for utilisation. Women are known for regularity of dues, they are law abiding and since it is the decision of the whole group that certain due is to be levy on members, it becomes imperative for them to comply.

Also the result in the Table 3b. The participation mean score was 9.16. The mean was used to categorise the respondents into two groups of low participation and high participation. The result shows that more than half (63.4\%) of the beneficiaries had high level of participation while the remaining $36.6 \%$ had low level of participation. Based on the findings, it can be concluded that appreciable percentage participated in various activities of the project, which could be attributed to their having basic education. Studies on participatory development pointed out that the better educated the members of the community, the higher their participation in development projects.

Table 3a: Distribution of beneficiaries on the level of participation in DELPHE project

\begin{tabular}{lllll}
\hline S/N & Participation in DELPHE activities & Mean & $\begin{array}{l}\text { Standard } \\
\text { deviation }\end{array}$ & Rank \\
\hline 1 & Contributions in decisions making in & 0.86 & 0.72 & $1^{\text {st }}$ \\
2 & $\begin{array}{l}\text { DELPHE project } \\
\text { Meeting attendance }\end{array}$ & 0.85 & 0.70 & $2^{\text {nd }}$ \\
3 & $\begin{array}{l}\text { Participation in training in processing } \\
\text { activities }\end{array}$ & 0.84 & 0.70 & $3^{\text {rd }}$ \\
4 & $\begin{array}{l}\text { Regularity of dues payment towards } \\
\text { project }\end{array}$ & 0.83 & 0.69 & $4^{\text {th }}$ \\
5 & Participation in group formation & 0.82 & 0.63 & $5^{\text {th }}$ \\
6 & Provide required information at meetings & 0.81 & 0.60 & $6^{\text {th }}$ \\
7 & Obtaining revolving loan & 0.63 & 0.56 & $7^{\text {th }}$ \\
8 & Procurement of processing equipment & 0.59 & 0.48 & $8^{\text {th }}$ \\
9 & Distribution / handling over of processing & 0.55 & 0.43 & $9^{\text {th }}$ \\
& equipments & & & \\
\hline
\end{tabular}

Source: Field survey, 2014 
Creative commons User License: CC BY-NC-ND

Abstracted by: EBSCOhost, Electronic Journals Service (EJS),

Google Scholar, Directory of Open Access Journals (DOAJ),

Journal Seek, Scientific Commons,

Food and Agricultural Organization (FAO), CABI and Scopus
Journal of Agricultural Extension

Vol. XX (X) XXXXXXX, 20XX

ISSN(e): 24086851; ISSN(Print); $1119944 X$

http://journal.aesonnigeria.org

http://www.ajol.info/index.php/jae

Email: editorinchief@aesonnigeria.org

Table 3b: Respondents' category of participation in DELPHE project activities

\begin{tabular}{lllll}
\hline $\begin{array}{l}\text { Level } \\
\text { participation }\end{array}$ & Min & Max & Mean & SD \\
\hline Low $(0-8)$ & 0.0 & 18.0 & 9.16 & 4.92 \\
High $(9-18)$ & & & & \\
Total & & & & \\
\hline
\end{tabular}

Source: Field Survey, 2014

\section{Welfare Status of the Respondents}

\section{Monthly household and actual per capita expenditure}

The respondents per capital expenditure derived by dividing the household expenditure by the household size of the respondents is presented on Table 4. It shows that households of the beneficiaries of DELPHE project spent \#12,091.45 on food purchases monthly, $\$ 27,688.53$ on education per month , spent $\$ 1,216.00$ on health monthly. The expense incurred on clothing in a month by households of beneficiaries was 2725.59. The Table further reveals that the average mean household expenditure of beneficiaries was \#1,730.90. It means that beneficiaries of DELPHE project spend on monthly household expenditure This could be attributed to more income generated by the beneficiaries that enables them have purchasing power on all the items of household expenditure which indicate better welfare status. 
Creative commons User License: CC BY-NC-ND

Abstracted by: EBSCOhost, Electronic Journals Service (EJS),

Google Scholar, Directory of Open Access Journals (DOAJ),

Journal Seek, Scientific Commons,

Food and Agricultural Organization (FAO), CABI and Scopus
Journal of Agricultural Extension

Vol. XX (X) XXXXXXX, 20XX

ISSN(e): 24086851; ISSN(Print); $1119944 X$

http://journal.aesonnigeria.org

http://www.ajol.info/index.php/jae

Email: editorinchief@aesonnigeria.org

Table 4: Mean expenditure on household basic items by beneficiaries of DELPHE project

\begin{tabular}{|c|c|c|}
\hline \multirow[t]{2}{*}{ Household basic item } & \multicolumn{2}{|l|}{ Beneficiaries } \\
\hline & 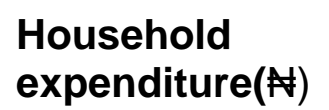 & $\begin{array}{l}\text { Percapitaexpen } \\
\text { diture( } \#)\end{array}$ \\
\hline $\begin{array}{l}\text { Food purchases } \\
\text { Imputed own consumption }\end{array}$ & $\begin{array}{r}12,091.45 \\
1,977.64\end{array}$ & $\begin{array}{r}1,677.39 \\
274.29\end{array}$ \\
\hline Education & $27,688.53$ & $3,840.29$ \\
\hline Health & $4,826.86$ & 669.46 \\
\hline $\begin{array}{l}\text { Bills on utilities (Water, } \\
\text { electricity) }\end{array}$ & $1,216.00$ & 168.65 \\
\hline Clothing & $2,725.59$ & 378.02 \\
\hline Rent (actual or imputed) & $1,500.00$ & 500.43 \\
\hline Household maintenance & $1,338.21$ & 185.60 \\
\hline Ceremonial expenditure & $1,547.56$ & 214.64 \\
\hline Transportation & $1,531.70$ & 212.44 \\
\hline Taxes & 266.00 & 36.89 \\
\hline $\begin{array}{l}\text { Communication } \\
\text { Telephone }\end{array}$ & $2,116.09$ & 293.49 \\
\hline Remittance & 888.53 & 123.23 \\
\hline
\end{tabular}

Mean: household expenditure of beneficiaries $=\$ 41,730.90$, Std. $=$

\section{Categorisation of Respondents' Welfare Status}

Respondents' welfare status which was categorized using the mean ( $\$ 5837.13$ ) as the bench mark for those above mean as better-off while those below the mean as worse-off.

The result in Table 5 shows that the majority (83.3\%) of the respondents were better off while only $31.8 \%$ of them were worse off. This implies that most of the respondents had higher welfare, this may be due to their participation in 
Creative commons User License: CC BY-NC-ND

Abstracted by: EBSCOhost, Electronic Journals Service (EJS),

Google Scholar, Directory of Open Access Journals (DOAJ),

Journal Seek, Scientific Commons,

Food and Agricultural Organization (FAO), CABI and Scopus
Journal of Agricultural Extension

Vol. XX (X) XXXXXXX, 20XX

ISSN(e): 24086851; ISSN(Print); $1119944 X$

http://journal.aesonnigeria.org

http://www.ajol.info/index.php/jae

Email: editorinchief@aesonnigeria.org

the DELPHE project activities. Hence, DELPHE had helped improved the welfare status of beneficiaries.

Table 5 Categorization of the respondents' level of welfare status

$\begin{array}{lc}\text { Welfare } & \text { Pcore range } \\ \text { status } & \text { Mean }\end{array}$

\begin{tabular}{llll}
\hline Better off & (N5,837- N 16,500) & 83.3 & N 5,837 \\
Worse off & (N 750- N 5836) & 16.7 & \\
\hline
\end{tabular}

Source: Field Survey, 2014

\section{Relationship between Respondents' Level of Participation in DELPHE Project Activities and their Welfare Status.}

Table 6 shows that there is significant relationship between respondent's level of participation in DELPHE project activities and welfare status of respondents at $r$-value of $0.424,(p=0.000)$. The implication of this result is that respondents of are expected to have improved welfare status as a result of the significance of their level of participation. The more their participation in DELPHE project activities the higher their welfare status.

Table 6: Relationship between respondents' level of participation in project activities and welfare status using PPMC

$\begin{array}{llll}\text { Variables } & N & \text { r-value } & \text { p-value }\end{array}$

Level of participation in project

activities and welfare status

$216 \quad 0.424 \quad 0.000$

${ }^{*}$ Correlation is significant at 0.01 level (2 tailed)

\section{Conclusion and Recommendations}

The study revealed that finance is a notable constraint faced by the respondents of the project as it can dampen their enthusiasm. There is high level of participation of rural women agro-processors' in DELPHE project. The majority of the respondents were better- off after participating in the DELPHE project as it evidently improved their welfare status. 
Creative commons User License: CC BY-NC-ND

Abstracted by: EBSCOhost, Electronic Journals Service (EJS), Google Scholar, Directory of Open Access Journals (DOAJ),

Journal Seek, Scientific Commons,

Food and Agricultural Organization (FAO), CABI and Scopus
Journal of Agricultural Extension

Vol. XX (X) XXXXXXX, 20XX

ISSN(e): 24086851; ISSN(Print); $1119944 X$

http://journal.aesonnigeria.org

http://www.ajol.info/index.php/jae

Email: editorinchief@aesonnigeria.org

The following recommendations were made:

1. The Federal government through the ministries of Agriculture and women affairs should replicate other intervention programmes among women agro-processors in different state rural communities to improve their welfare status.

2. there is need for provision of loan at a reduced interest rate by financial institutions such as banks, micro-finance for the rural women to expand their processing business.

Acknowledgement: The financial contributions of the DELPHE project towards the completion of this study is hereby acknowledged

\section{References}

Akinola, O. (2014). Community Driven Development in Nigeria: www.academia.edu/ community driven development in Nigeria.

Fabiyi, E.F. and Akande, K. (2015). Economic Empowerment for Rural Women In Nigeria: Poverty Alleviation through Agriculture. Journal of Agricultural Science Vol.7No.9 Pp 1916-9160.

Hussain A. (2009). Participation and Perceived Effectiveness of Community-Based Poverty Reduction Projects in Ekiti State, Nigeria. Unpublished Thesis in the Department of Agricultural Extension and Rural Development, University of Ibadan.

Dutt, B. (2014). Strategies for Setting and Running of Small Scale Enterprise. Journal of Agricultural Extension and Rural Development. Vol.6(1)Pp35-43.

Development Partnership in Higher Education (DELPHE) (2008). Project Implementation manual, Obafemi Awolowo University lle- Ife.

International Fund for Agricultural Development, IFAD (2011). Gender Perspective Focus on the Rural Poor: An overview of Gender Issues in IFAD Assisted Projects Report. Rome. 1-20.

Koyenikan, M. J. and Ikharea V. E. (2014). Participation of Women in the Third National Fadama Development Programme in Edo State, Nigeria. Journal of Agriculture Extension. Vol. 18(2) Pp 147 - 157 
Creative commons User License: CC BY-NC-ND

Abstracted by: EBSCOhost, Electronic Journals Service (EJS), Google Scholar, Directory of Open Access Journals (DOAJ),

Journal Seek, Scientific Commons,

Food and Agricultural Organization (FAO), CABI and Scopus
Journal of Agricultural Extension

Vol. XX (X) XXXXXXX, 20XX

ISSN(e): 24086851; ISSN(Print); 1119944X

http://journal.aesonnigeria.org

http://www.ajol.info/index.php/jae

Email: editorinchief@aesonnigeria.org

Mafimisebi. T.E. (2007). A comparative Economic Analysis of Two Cassava-Based Businesss Activities Exclusive to the Female Gender in Oyo State, Nigeria. Journal of Agricultural Extension vol. 10

Oakely, E.A. (2002). Projects with People. The practice. The Practice of Participation in Rural Developments. Geneva. ILO Pp.98-112.

Ogidefa, I. (2010) Rural development in Nigeria. Concept approach, challenges and prospects.http://socyberty.com/issues/rural-development-in-nigeria-conceptapproaches-challenges-and-prospects/Retrieved $9^{\text {th }}$ July 2012.

Olawuyi S.O and Adetunji M.O. (2013). Assessment of Rural Households Poverty in Nigeria: Evidence from Ogbomoso Agricultural Zone of Oyo state Nigeria. Journal of Scientific Research and Reports 2(1) Pp 35-45.

Omotola, J. S (2008). Combating Poverty for Sustainable Human Development in Nigeria: The continuing struggle. Journal of Poverty, Vo12(4), Pp 496- 517.

Samuel, I.O. (2014). Achieving Sustainable Poverty Reduction in Nigeria through Local Economic Development Strategies. American Journal of Rural Development. Vol.2 (1) Pp 31-42 